\title{
PERSEPSI MASYARAKAT TERHADAP DAMPAK LINGKUNGAN USAHA PETERNAKAN BROILER DI LINGKUNGAN PEKANGLAKBU, KELURAHAN TETEBATU, KECAMATAN PALLANGGA, KABUPATEN GOWA
}

\section{Community Perception on The Impact of Broiler in Pekanglakbu Village, Tetebatu Sub District, Pallangga District, Gowa Regency}

\author{
Aminuddin Saade*, Idris, dan Diliyanti Ashari \\ Politeknik Pembangunan Pertanian Gowa \\ Jl Malino km 7. Romanglompoa, Kecamatan Bontomarannu, Kabupatan Gowa Provinsi Sulawesi Selatan \\ *e-mail: aminsaade.63@gmail.com
}

Received: 24 Agustus 2021; Accepted: 29 November 2021; Published: 25 Desember 2021

\begin{abstract}
ABSTRAK
Penelitian ini dilaksanakan di Lingkungan Pekanglakbu, Kelurahan Tetebatu, kecamatan Pallangga, Kabupaten Gowa pada bulan April - Mei 2021.Sedangkan pelaksanaan penyuluhan dilaksankan bulan Juli 2021 di Kelompok Tani Pa'laissseng I, Desa Pallangga Kecamatan Pallangga, Kabupaten Gowa, Provinsi Sulawesi Selatan. Jenis penelitian ini dalah penelitian kuantitatif deskriptif yang menggambarkan suatu fenomena, dalam hal ini persepsi masyarakat Terhadap Dampak Lingkungan Usaha Peternakan Boiler Dilingkungan Pekanglakbu, Kelurahan Tetebatu, Kecamatan Pallangga, Kabupaten Gowa. Hasil penelitian ini diketahui bahwa Persepsi Masyarakat Terhadap Dampak Lingkungan Usaha Peternakan Boiler Dilingkungan Pekanglakbu, Kelurahan Tetebatu, Kecamatan Pallangga, Kabupaten Gowa termasuk kategori terganggu. Hal ini dikarenakan responden merasa terganggu dengan dampak lingkungan usaha peternakan broiler tersebut maka dari itu peternakan broiler di lingkungan tersebut termasuk peternakan yang membuat masyarakat terganggu terhadap dampak lingkungan dari peternakan broiler tersebut. Hasil evaluasi penyuluhan petani/peternak terhadap dampak lingkungan usaha peternakan broiler menunjukan bahwa ada peningkatan pengetahuan $26,6 \%$ dan sikap $35 \%$.
\end{abstract}

Kata kunci : Persepsi masyarakat, dampak lingkungan, peternakan broiler

\section{PENDAHULUAN}

Usaha peternakan broiler dikatakan sebagai usaha yang ikut mencemari lingkungan (Fauziah, 2009). Berdasarakan tanggapan tersebut (Setyowati, 2008) mengakatan banyaknya peternakan broiler yang berada di lingkungan masyarakat dirasakan mulai mengganggu oleh warga terutama peternakan ayam yang lokasinya dekat dengan pemukiman penduduk. Masyarakat banyak mengeluhkan dampak buruk dari kegiatan usaha peternakan broiler karena masih banyak peternak yang mengabaikan penanganan limbah dari usahanya. Limbah peternakan yang berupa

Diterbitkan Oleh, Unit Penelitian dan Pengabdian Masyarakat, Politeknik Pembangunan Pertanian Gowa http://ejournal.polbangtan-gowa.ac.id feses, dan sisa pakan serta air dari pembersihan ternak dan kandang menimbulkan pencemaran lingkungan masyarakat di sekitar lokasi peternakan tersebut. Dari uraian di atas, yang menjadi permasalahan adalah peternak dalam menjalankan usahanya masih mengabaikan aspek-aspek Lingkungan, sehinggga menimbulkan dampak pencemaran lingkungan. Untuk itu diperlukan upaya yang tepat untuk dapat mengatasi dampak pencemaran lingkungan dari usaha peternakan broiler sehingga keberadaannya tidak mengganggu masyarakat. 
Dampak lingkungan adalah perubahan lingkungan yang diaakibatkan oleh suatu kegiatan,awal masalah lingkungan merupakan setiap kegiatan manusia baik dalam riak kecil maupun dalam riak yang lebih besar, dalam lingkungan yang insidential ataupun rutin, selalu akan memperoleh lingkungannya. Sebaiknya, manusia tidak akan lepas pula dari pengaruh lingkungan, baik yang datang dari alam sekitar (fisik maupun non fisik), dari hubungan individu ataupun masyarakat (siahan, 2004).

(Setyono, 2011) melaporkan bahwa standar kelayakan dalam mendirikan kandang untuk usaha peternakan adalah tidak menggangu lingkungan sekitar, usaha dibangun dilingkungan yang dijamin secara hukum, usaha berada di daerah yang memiliki potensi sumber daya terutama pakan yang cukup tinggi, sebaiknya kandang tidak dibangun di daerah rawan kerusakan atau gangguan lingkungan dari aspek tata letak, sebaiknya posisi kandang lebih tinggi dari daerah sekitrnya lokasi kandang mudah di jangkau oleh kendaran roda empat. Dalam aturan permentan, no 40 tahun 2011 menyebutkan bahwa jarak antara peternakan broiler dengan lingkungan pemukiman minimal 500 meter dari pagar terluar.

Selain lokasi peternakan broiler yang dekat dengan pemukiman warga, usaha peternakan broiler juga menimbulkan limbah yang dinilai cukup mengganggu warga yang bermukiman disekitar kandang. Limbah ternak merupakan hasil sisa buangan dari suatu kegiatan usaha peternakan seperti usaha pemeliharaan ternak, rumah potong hewan dan sebagainya.semakin berkembangnya usaha peternakan limbah yang dihasilkan semakin meningkat.

Limbah peternakan meliputi semua kotoran yang dihasilkan dari suatu kegiatan usaha peternakan baik berupa limbah padat, cair,gas maupun sisa pakan. Limbah merupakan semua limbah yang berbentuk padatan atau dalam fase padat ( kotoran ternak, ternak yang mati, atau isi perut dari pemotongan ternak ). Limbah cair adalah semua limbah yang berbentuk cairan atau dalam fase cairan (air seni atau urine, air dari pencucian alat-alat) sedangkan limbah gas adalah semua limbah berbentuk gas atau dalam fase gas. Limbah yang dihasilkan oleh usaha broiler dapat mencemari lingkungan, terutama pada daerah padat Diterbitkan Oleh, Unit Penelitian dan Pengabdian Masyarakat, Politeknik Pembangunan Pertanian Gowa http://ejournal.polbangtan-gowa.ac.id penduduk atau dekat dengan pemukiman warga.

Persepsi dalam arti umum adalah pandangan seseorang terhadap sesuatau yang akan membuat respon bagaimana, dengan apa seseorang akan bertindak. Persepsi seseorang proses aktif yang memegang peran, bukan hanya stimulus yang mengenalnya tetapi juga individu sebagai satu kesatuan dengan pengalaman - pengalamanya, motivasi serta sikapnya yang relevan dalam menanggapi stimulus (Walgito,2002 ).

Persepsi adalah proses internal yang mana telah diakui oleh individu ketika menyeleksi dan mengatur stimuli yang berasal dari luar. Stimuli ini ditangkap oleh indera yang dimiliki seseorang, kemudian secara spontan perasaan dan pikiran individu akan memberikan makna dari stimuli yang ada tersebut. Secara sederhana, dapat dikatakan jika persepsi adalah proses individu dalam memahami hubungan atau kontak dengan dunia yang ada di sekelilingnya. (Suranto, 2010). Berdasarkan uraian latar belakang tersebut diatas, maka dilakukan penelitian mengenai Persepsi Masyarakat Terhadap Dampak Lingkungan Usaha Peternakan Broiler Di Lingkungan Pekanglakbu, Kelurahan Tetebatu, Kecamatan Pallangga, Kabupaten Gowa.

\section{METODE PENELITIAN}

\section{Tempat dan Waktu}

Penelitian ini dilaksanakan di Lingkungan Pekanglakbu, Kelurahan Tetebatu, kecamatan Pallangga, Kabupaten Gowa pada bulan April - Mei 2021.Sedangkan pelaksanaan penyuluhan dilaksankan bulan Juli 2021 di Kelompok Tani Pa'laissseng I, Desa Pallangga Kecamatan Pallangga, Kabupaten Gowa, Provinsi Sulawesi Selatan.

\section{Alat}

Alat yang digunakan dalam penelitian ini berupa alat tulis menulis, kuesioner, leaflet/folder, dan kamera.

\section{Metode Penelitian}

Metode penelitian telah digunakan adalah penelitian kuantitatif deskriptif, yaitu penelitian menjelaskan atau menggambarkan suatu fenomena,dalam hal ini Persepsi Masyarakat 
Terhadap Dampak Lingkungan Usaha Peternakan Broiler Di Lingkungan Pekanglakbu, Kelurahan Tetebatu Kecamatan Pallangga, Kabupaten Gowa.

\section{Populasi dan Sampel}

(Margono 2004) bahwa populasi adalah keseluruhan data yang menjadi pusat perhatian seorang peneliti dalam ruang lingkup dan waktu yang telah ditentukan. Populasi berkaitan dengan data data, jika seorang manusia memberikan data jika seseorang manusia memberikasuatu data, maka ukuran atau banyaknya manusia. (Arikunto, 2006) sampel adalah sebagian atau sebagai wakil populasi yang akan diteliti. Jika penelitian yang dilakukan sebagian dari populasi maka bisa dikatakan bahwa penelitian tersebut adalah penelitian sampel.

Populasi merupakan masyarakat Lingkungan Pekanglakbu, Kelurahan Tetebatu, Kecamatan Pallangga, Kabupaten Gowa yang bermukim disekitar dari peternakan broiler tersebut. Adapun jumlah total populasi masyarakat yang tinggal berdekatan dengan peternakan broiler yaitu sebanyak 389 orang

Karena jumlah populasi yang cukup besar yaitu 389 orang, maka dilakukan pengambilan sampel. Untuk menentukan besarnya ukuran sampel maka dilakukan dengan menggunakan statistic deskriptif berdasarkan rumus Slovin dalam Umar (2003). Tingkat kelonggaran $15 \%$ digunakan dengan dasar jumlah tidak lebih dari 2000 populasi (Sugiyono, 2003).

\section{Teknik Pengumpulan Data Analisis Data}

Jenis data yang digunakan yaitu data kuantitatif. Sumber data yang di gunakan dalam penelitian. Data primer adalah data yang diperoleh dari hasil wawancara langsung dengan masyarakat yang lokasi dekat usaha peternakan broiler dengan menggunakan kuisioner yang terdiri atas nama, umur, jenis kelamin. Data sekunder adalah data yang diperoleh melalui dokumen - dokumen pada kantor desa dan kantor BPP serta instansi terkait lainnya.
Teknik pengumpulan data dilakukan dengan beberapa tahap yaitu :

1. Wawancara, yaitu pengumpulan data dengan cara menggunakan kuesioner atau petanyaan pertanyaan yang telah disiapkan

2. Informasi yang diperlukan dapat beragam kedudukannya dalam struktur sosial, seperti tokoh adat/ agama, petani dan pemerintah setempat.

3. Observasi yaitu mengumpulkan data dengan cara mengamati langsung objek yang ditelti. Untuk melengkapi data diperoleh dari wawancara dan pencatatan.

4. Dokumentasi, untuk melengkapi data yang diperoleh dalam kegiatan penelitian.

\section{Analisis Data}

Analisa data yang digunakan pada penelitian ini statistik deskriptif dengan menggunakan pengelompokan, penyederhanaan, serta penyajian data seperti tabel distribusi frekuensi dan pengukuran dengan menggunakan skala likert.

(Riduwan, 2008) bahwa skala likert digunakan untuk mengukur sikap, pendapat dan persepsi seseorang atau sekelompok tentang kejadian atau gejala sosial. Dengan menggunakan skala likert, maka variabel yang akan diukur dijabarkan menjadi indikator-indikator yang dapat diukur. Kemudian indikator tersebut dijadikan sebagai titik tolak untuk menyusun item-item instrumen yang dapat berupa pernyataan atau pertanyaan. Setiap jawaban dihubungkan dengan bentuk pernyataan atau dukungan persepsi yang diungkapkan dengan kata-kata yang dikategorikan sebagai berikut :

$\begin{array}{ll}\text { Sangat Terganggu } & : 5 \\ \text { Terganggu } & : 4 \\ \text { Cukup Terganggu } & : 3 \\ \text { Tidak Terganggu } & : 2 \\ \text { Sangat Tidak Terganggu } & : 1\end{array}$

\section{Parameter Pengamatan}

Parameter yang di amati yaitu persepsi masyarakat terhadap limbah padat, limbah cair dan bau pada usaha peternakan broiler.

Diterbitkan Oleh, 
DOI: 10.52625/j-agr-sosekpenyuluhan.v17i2.200

Tabel 1. Parameter pengamatan

\begin{tabular}{cll}
\hline Variabel & \multicolumn{1}{c}{ Sub variabel } & \multicolumn{1}{c}{ Indikator } \\
\hline Persepsi masyarakat & a. Bau & $\begin{array}{l}\text { 1. Bau tidak sedap } \\
\end{array}$ \\
& & 2. Sangat menyengat \\
& b. Pencemaran air & 3. Saluran air \\
& c. Pencemaran limbah & 4. Ditumpuk \\
& padat & \\
\hline
\end{tabular}

\section{Bau (Penciuman)}

Untuk mengukur persepsi masyarakat terhadap dampak lingkungan usaha peternakaan broiler berdasarkan bau dengan menggunakan asumsi dasar menggunakan interval kelas dan rentang kelas. Dengan nilai tersebut dapat dibuat kategori sebagai berikut:

$\begin{array}{ll}\text { Sangat Terganggu } & : 369,6-440 \\ \text { Terganggu } & : 299,2-369,6 \\ \text { Cukup Terganggu } & : 228,8-299,2 \\ \text { Tidak Terganggu } & : 158,4-228,8 \\ \text { Sangat Tidak Terganggu } & : 88-158,4\end{array}$

\section{Pencemaran air}

Untuk mengukur persepsi masyarakat terhadap dampak lingkungan usaha peternakaan broiler berdasarkan pencemaran air dengan menggunakan asumsi dasar menggunakan interval kelas dan rentang kelas. Dengan nilai tersebut dapat dibuat kategori sebagai berikut:

$\begin{array}{ll}\text { Sangat Terganggu } & : 184,8-220 \\ \text { Terganggu } & : 149,6-184,8 \\ \text { Cukup Terganggu } & : 114,4-149,6 \\ \text { Tidak Terganggu } & : 79,2-114,4 \\ \text { Sangat Tidak Terganggu } & : 44-79,2\end{array}$

\section{Limbah}

Untuk mengukur persepsi masyarakat terhadap dampak lingkungan usaha peternakaan broiler berdasarkan Limbah dengan menggunakan asumsi dasar menggunakan interval kelas dan rentang kelas. Dengan nilai tersebut dapat dibuat kategori sebagai berikut :

$\begin{array}{ll}\text { Sangat Terganggu } & : 184,8-220 \\ \text { Terganggu } & : 149,6-184,8 \\ \text { Cukup Terganggu } & : 114,4-149,6\end{array}$

Tidak Terganggu

: 79,2-114,4

Sangat Tidak Terganggu

: 44-79,2

\section{Nilai Persepsi Secara Keseluruhan}

Untuk mengetahui keseluruhan nilai dari Persepsi Masyarakat Terhadap Dampak Lingkungan Usaha Peternakan Broiler Di Lingkungan Pekanglakbu Kelurahan Tetebatu Kecamatan Pallangga Kabupaten Gowa, maka digunakan klasifikasi/pengelompokan. Dengan nilai tersebut dapat dibuat kategori sebagai berikut:

$\begin{array}{ll}\text { Sangat Terganggu } & : 739,2-880 \\ \text { Terganggu } & : 598,4-739,2 \\ \text { Cukup Terganggu } & : 457,6-598,4 \\ \text { Tidak Terganggu } & : 316,8-457,6 \\ \text { Sangat Tidak Terganggu } & : 176-316,8\end{array}$

\section{Evaluasi Penyuluhan}

\section{Menetapkan Tujuan Evaluasi}

Menetapkan tujuan evaluasi berfungsi untuk mengetahui tingkat pengetahuan, dan sikap petani yang digunakan untuk menganalisis secaara deskriptif tentaang penggambaransikap petani dengaan menggunakan data skala ordinaal yangg alat ukurnya ialah pengetahuan dan sikap. Adapun skor yang digunakan paling tinggi skor 4 dan paling rendah skor 1 .

\section{Memilih Metode Evaluasi}

Evaluasi terdiri dari evaluasi awal dan evaluasi akhir. Metode yang digunakan untuk menganalisis tingkat respons peternak terhadap materi penyuluhan adalah dengan menggunakan skala likert kemudian ditabulasi dan di gambarkan dalam bentuk garis continuum (Padmowihardjo, 2002). Untuk mengetahui tingkat pengetahuan, dan sikap petani/ peternak digunakan analisis diskriptif

Diterbitkan Oleh, 
yaitu menggambarkan sikap peternak/petani dengan menggunakan data skala ordinal (skala likert) sedangkan alat ukur tingkat pengetahuan dan sikap menggunakan Rating Scale. Adapun skornya yang digunakan adalah, skor 4 sangat mengetahui (SM), skor 3 mengetahui (M), skor 2 Cukup mengetahui $(\mathrm{CM})$ dan skor 1 tidak mengetahui (TM).

\section{Instrumen Evaluasi Penyuluhan}

Pengetahuan dan sikap responden tentang persepsi masyarakat terhadap dampak lingkungan usaha peternakan broiler di lingkungan pekanglakbu, kelurahantetebatu, kecamatan pallangga, kabupaten gowa diukur dengan alat bantu berupa kuesioner dalam bentuk pertanyaan sebanyak 10 pertanyaan. Untuk mengukur tingkat pengetahuan 5 pertanyaan, dan untuk mengukur sikap 5 pertanyaan.

\section{Menetapkan Sampel dan Populasi}

Penentuan jumlah sampel dilakukan dengan teknik purposive sampling (sampling pertimbangan), yakni ditentukan secara langsung dengan pertimbangan kebutuhan materi serta melihat potensi peternakan dan jenis komoditas yang ada di desa pallangga, kabupaten gowa. Dengan jumlah petani/peternak sebanyak 25 orang.

\section{Evaluasi Hasil Penyuluhan}

Efektivitas penyuluhan diperoleh dari hasil evaluasi penyuluhan yang dilakukan dengan tujuan untuk mengetahui sejauh mana keberhasilan penyuluhan yang telah dilakukan terhadap peningkatan perubahan perilaku sasaran. Efektivitas penyuluhan dihitung dengan rumus Ginting (1991).

\section{HASIL DAN PEMBAHASAN}

\section{Persepsi Masyarakat}

Persepsi masyarakat adalah suatu proses penilaian seseorang terhadap objek tertentu berupa tanggapan yang diberikan oleh masyarakat mengenai peternakan broiler yang berada di Lingkungann Pekanglakbu Kelurahan Tetebatu Kecamatan Pallangga Kabupaten Gowa.

Tabel 2. Indikator variabel penelitian ini

\begin{tabular}{|c|c|c|}
\hline No & Variabel & Indikator Variabel Penelitian \\
\hline 1. & $\mathrm{Bau}$ & Aroma yang tidak sedap yang berasal dari peternakan broiler \\
\hline 2. & Pencemaran saluran air & dimana pencemaran yang ditimbulkan peternakan broiler \\
\hline 3. & Pencemaran Limbah & $\begin{array}{l}\text { kondisi lingkungan dari peternakan broiler yang tidak baik } \\
\text { untuk dilihat oleh indera karena limbah tersebut hanya } \\
\text { dibiarkan menumpuk }\end{array}$ \\
\hline
\end{tabular}

\section{Bau}

Bau adalah aroma yang tidak sedap yang berasal dari peternakan broiler sehingga masyarakat kurang tahan akan hal tersebut. Kadang kala ada kadang kala tidak tercium sebab bau muncul tergantung datangnya angin atau dikala musim penghujan. Untuk melihat persepsi masyarakat Di Lingkungan Pekanglakbu Kelurahan Tetebatu Kecamatan Pallangga Kabupaten Gowa, dengan sub variabel bau dapat dilihat pada tabel 3. Berdasarkan tabel 3 dan 4.
Menunjukan bahwa total skor untuk sub variabel bau di peroleh 428 skor dengan kategori sangat terganggu yang berarti berada di kategori tertinggi. Diantara indikator diperoleh nilai skor yang sangat tinggi yaitu 210 skor pada indikator sangat terganggu dengan adanya bau dengan kategori tidak terganggu. Tinggi skor tersebut disebabkan karena sebagian masyarakat merasa sangat terganggu dengan adanya bau ,hal ini sesuai dengan pendapat sudarma dan racman 2012 ), bahwa tanggapan seseorang, dimana bau peternakan berasal dari pakan, feses pupuk.

Diterbitkan Oleh, 
DOI: $10.52625 /$ j-agr-sosekpenyuluhan.v17i2.200

Tabel 3. Jawaban responden mengenai persepsi masyarakat dengan sub variabel bau indikator bau di lingkungan Pekanglakbu Kelurahan Tetebatu Kecamatan Pallangga Kabupaten Gowa

\begin{tabular}{llcccc}
\hline Indikator & Kategori jawaban & Nilai skor & $\begin{array}{c}\text { Frekuensi } \\
\text { ( orang })\end{array}$ & total & presentase \\
\hline Bau & Sangat terganggu & 5 & 42 & 210 & 95,45 \\
& terganggu & 4 & 2 & 8 & 4,54 \\
& Cukup terganggu & 3 & 0 & 0 & 0 \\
& Tidak tergangu & 2 & 0 & 0 & 0 \\
& Sangat tidak & 1 & 0 & 0 & 0 \\
& terganggu & & & 218 & 100 \\
\hline
\end{tabular}

Tabel 4. Jawaban responden mengenai persepsi masyarakat dengan sub variabel bau, indikator bau tidak mudah hilang di lingkungan Pekanglakbu Kelurahan Tetebatu, Kecamatan Pallangga Kabupaten Gowa

\begin{tabular}{llcccc}
\hline Indikator & Kategori jawaban & Nilai skor & $\begin{array}{c}\text { Frekuensi } \\
\text { (orang) }\end{array}$ & total & presentase \\
\hline Bau Tidak & Sangat terganggu & 5 & 34 & 170 & 77,27 \\
Mudah & Terganggu & 4 & 10 & 40 & 22,72 \\
Hilang & Cukup terganggu & 3 & 0 & 0 & 0 \\
& Tidak tergangu & 2 & 0 & 0 & 0 \\
& Sangat tidak & 1 & 0 & 0 & 0 \\
\hline & terganggu & & 44 & 218 & 100 \\
\hline
\end{tabular}

\section{Pencemaran air}

Pencemaran air adalah kondisi lingkungan dari peternakan broiler yag tidak baik untuuk dilihat oleh indera karena limbah cair tersebut hanya di buang begitu saja disaluran air di tempat pemukiman yang padat. Limbah cair tersebut dibiarkanpada saluran pembuangan. Untuk melihat persepsi masyarakat di Lingkuungan Pekanglakbu Kelurahan Tetebatu Kabupten Gowa. Mengenai persepsi masyarakat terhaadap dampak lingkungan usha peternakan broiler dengan suub variabel pencemaran air dapat dilihat pada tabel 5 .

Tabel 5. Jawaban responden mengenai persepsi masyarakat dengan sub variabel pencemaran air di lingkungan Pekanglakbu Kelurahan Tetebatu Kecamatan Pallangga Kabupaten Gowa

\begin{tabular}{llcccc}
\hline Indikator & \multicolumn{1}{c}{ Kategori jawaban } & Nilai skor & $\begin{array}{c}\text { Frekuensi } \\
\text { (orang) }\end{array}$ & Total & Persentase \\
\hline Air & Sangat terganggu & 5 & 8 & 40 & 18,18 \\
berbau & Terganggu & 4 & 0 & 0 & 0 \\
& Cukup terganggu & 3 & 0 & 0 & 0 \\
& Tidak terganggu & 2 & 36 & 72 & 81,81 \\
& Sangat tidak terganggu & 1 & 0 & 0 & 0 \\
\hline
\end{tabular}

Berdasarkan tabel 5. Menunjukan bahwa total skor untuk sub variabel pencemaran air yang diperoleh yaitu 112 skor dengan kategori tidak Diterbitkan Oleh, Unit Penelitian dan Pengabdian Masyarakat, Politeknik Pembangunan Pertanian Gowa http://ejournal.polbangtan-gowa.ac.id terganggu yang berarti berada pada kategori rendah. Diantara indikator diperoleh nilai skor yang sangat tinggi 72 skor pada indikator tidak terganggu 
dengan pencemaran air. Rendahnya skor tersebut disebabkan karena sebagian masyarakat di Lingkungan Pekanglakbu merasa tidak terganggu dengan pencemaran air dikarenakan pembuangan limbah cair yang memiliki aliran tersendiri sehingga tidak mengganggu pemukiman warga.

Hal ini sesuai pendapat (Lahamma 2000) yang menyatakan bahwa harusnya ada pengolahan limbah yang benar agar tidak mengganggu warga dan limbah tersebut sebaiknya diolah agar tidak mencemari lingkungan.

\section{Limbah}

Limbah adalah kondisi lingkungan peternakan broiler yang mempunyai hal positifnya dapat di jadikan pupuk kandang dan hal negatifnya tidak bagus untuk dilihat oleh indera penglihatan dan penciuman. Untuk melihat Persepsi Masyarakat Di Lingkungan Pekanglakbu Kelurahan Tetebatu Kecamatan Pallangga Kabupaten Gowa, mengenai persepsi masyarakat terhadap dampak lingkungan usaha peternakan broiler dengan sub variabel limbah dapat dilihat pada tabel 6 .

Tabel 6. Jawaban responden mengenai persepsi masyarakat dengan sub variabel pengolahan limbah di lingkungan Pekanglakbu Kelurahan Tetebatu Kecamatan Pallangga Kabupaten Gowa

\begin{tabular}{llcccc}
\hline Indikator & \multicolumn{1}{c}{ Kategori jawaban } & Nilai skor & $\begin{array}{c}\text { Frekuensi } \\
\text { (orang) }\end{array}$ & Total & Persentase (\%) \\
\hline Di tumpuk & Sangat Terganggu & 5 & 8 & 40 & 18,18 \\
& Terganggu & 4 & 0 & 0 & 0 \\
& Cukup Terganggu & 3 & 0 & 0 & 0 \\
& Tidak Terganggu & 2 & 36 & 72 & 81,81 \\
& Sangat Tidak & 1 & 0 & 0 & 0 \\
& Terganggu & & 44 & 112 & 100 \\
\hline
\end{tabular}

Berdasarkan Tabel 6. menunjukan bahwa total skor yang diperoleh yaitu 112 skor yang berarti berada pada kategori rendah, meskipun demikian dari indikator yang terdiri dari ditumpuk. Diantara indikator tersebut diatas diperoleh nilai skor yang sangat tinggi yaitu 72 skor pada indikator ditumpuk tersebut dengan kategori tidak terganggu. Tinggi skor tersebut disebabkan karena sebagian masyarakat Lingkungan Pekanglakbu merasa tidak terganggu, dikarenakan fesesnya dijual di pengepul untuk dibuat sebagai pupuk kandang adapula merasa sangat terganggu dengan pengolahan limbah dikarenakan cukup memakan waktu untuk menjual fese tersebut. Hal ini sesuai pendapat ( Sudarma dalam Rachman 2012 ), yang mengatakan bahwa limbah ternak adalah suatu sumber daya yang bila tidak dimanfaatkan dengan baik, dapat menimbulkan masalah bagi peternakan itu sendiri maupun terhadap lingkungan. Semua limbah peternakan adalah bahan yang dapat diperbaharui, tak akan habis selama ternak ada. Bila limbah peternakan tidak dikelolah dengan baik akan mencemari atau memperburuk kondisi lingkungan setempat.

\section{Total Persepsi Secara Keseluruhan}

Penilaian masyarakat di Lingkungan Pekanglakbu, Kelurahan Tetebatu, Kecamatan Pallangga, Kabupaten Gowa terhadap persepsi keseluruhan dapat dilihat pada Tabel 7 . Berdasarkan tabel 7. Menunjukan bahwa hasil penilaian responden terhadap persepsi secara keseluruhan dengan total bobot 652 penilaian tersebut meliputi bau dan tidak mudah hilang, dengan bobot 428 , pencemaran air terdiri dari indikator saluran air berbau dengan bobot 112, serta limbah dengan indikator di tumpuk dengan bobot 112 .

Diterbitkan Oleh, 
DOI: $10.52625 /$ j-agr-sosekpenyuluhan.v17i2.200

Tabel 7. Hasil rekapitulasi penilaian masyarakat terhadap persepsi di lingkungan pekanglakbu kelurahan tetebatu Kecamatan Pallangga Kabupaten Gowa

\begin{tabular}{rll}
\hline \multicolumn{1}{c}{ Variabel } & \multicolumn{1}{c}{ Sub variabel } & Nilai \\
\hline Persepsi masyarakat & 1.Bau & 428 \\
& 2.Pencemaran air & 112 \\
& 3.Pencemaran limbah & 112 \\
\hline Jumlah & & 652 \\
\hline
\end{tabular}

\section{Evaluasi Penyuluhan Peternakan}

Evaluasi penyuluhan dilkukan untuk mengetahui pengetahuan dan sikap responden terhadap materi yang telah disampaikan. Evaluasi yang telah dilakukan adalah evaluasi awal dan evaluasi akhir. Alay yang digunakan untuk mengukur tingkat pengetahuan dan sikap Responden adalah kuesioner dengan jumlah pertanyaan sebanyak 5 untuk pengetahuan, dan 5 untuk sikap, sehingga total pertanyaan seluruhnya adalah 10, dengan nilai tertinggi adalah 4 dan nilai terendah 1. Tinggi rendhny tingkat pengetahuan Responden dapat ditentukan melalui jawaba Responden dari tiap-tiap pertanyaan dalam evaluasi awal dan akhir dengan Responden anggota pala'isseng I sebanyak 25 orang. Hasil evaluasi penyuluhan diharapkan dapat menggambarkan tercapai atau tidaknya program penyuluhan sebaagai gambaran hasil kegiatan penyuluhan yang telah dilaksanakan.

Tabel 8. Rata-rata tingkat pengetahuan dan sikap responden kelompok tani Pala'isseng I Desa Pallanga, Kabupaten Gowa, tahun 2021

\begin{tabular}{lccccccc}
\hline \multirow{2}{*}{ Deskripsi } & Skor & \multicolumn{3}{c}{ Nilai yang Diperoleh } & \multicolumn{2}{c}{ Perubahan } \\
\cline { 2 - 8 } & Maks & Tes Awal & $\%$ & Tes Akhir & $\%$ & Nilai & $\%$ \\
\hline Pengetahuan & 500 & 290 & $58 \%$ & 423 & $84,6 \%$ & 133 & $26,6 \%$ \\
Sikap & 500 & 283 & $56,6 \%$ & 456 & $91,6 \%$ & 173 & $35 \%$ \\
Jumlah & 1000 & 573 & & 879 & & 306 & \\
\hline
\end{tabular}

Berdasarkan table 8. Menunjukkan bahwa penyuluhan dengan materi persepsi masyarakat terhadap dampak lingkungn usaha peternakan broiler dapat mengubah tingkat pengetahuan dan sikap responden. Sebelum mengikuti penyuluhan, tingkat pengetahuan responden berada pada kategori mengetahui (58\%) dan tingkat sikap responden berada pada kategori setuju $(56,6 \%)$. Setelah mengikuti penyuluhan, tingkat pengetahuan dan sikap responden meningkat menjadi sangat mengetahui $(84,6 \%)$ dan sangat setuju $(91,6 \%)$.

\section{Efektivitas penyuluhan}

Berdasarkan hasil evaluasi awal dan evaluasi akhir maka diperoleh Efektivitas Penyuluhan dengan persentase $72,13 \%$. Dari hasil perhitungan yang telah dilakukan, maka dapat disimpulkan bahwa penyuluhan yang dilakukan Diterbitkan Oleh, Unit Penelitian dan Pengabdian Masyarakat, Politeknik Pembangunan Pertanian Gowa http://ejournal.polbangtan-gowa.ac.id dapat dikategorikan sebagai penyuluhan yang Efektitas.

\section{KESIMPULAN}

\section{Kesimpulan}

Berdasarkan hasil analisis dan pembahasan yang telah dilakukan, maka dapat diambil kesimpulan sebagai berikut:

1. Peneliti dapat menyimpulkan bahwa persepsi masyarakat terhadap dampak lingkungan usaha peternakan broiler di lingkungan pekanglakbu, kelurahan tetebatu, kecamatan pallangga, kabupaten gowa, pada indikator bau 95,45\% merasa sangat terganggu, sedangkan yang cukup terganggu berjumlah $4,54 \%$. Selanjutnya pada indikator bau tidak mudah hilang ada $77,27 \%$ merasa sangat terganggu sedangkan masyarakat yang terganggu ada $22,72 \%$. 
2. Pencemaran air, adapun persepsi masyarakat terhadap pencemaran air terhadap dampak lingkungan usaha peternakan broiler sejumlah $18,18 \%$ yang merasa sangat terganggu, sedangkan $81,81 \%$ masyarakat sangat tidak meras aterganggu diakibattkan saluran air dari limbah penceran tersebut memiliki saluran air tersendiri sehingga masyarakat tidak terlalu terganggu terhadap pencemaran tersebut.

3. Limbah, adapun persepsi masyarakat terhadap limbah daari peternakan broiler di pekanglakbu sejumlah $18,18 \%$ merasa sangat terganggu dan $81,81 \%$ merasa sangat tidak terganggu dikarenakanan limbah dari peternakan tersebut di kumpulkan dengan rapi dan di jual dipengepul.

4. Hasil evaluasi penyuluhan petani/peternak terhadap dampak lingkungan usaha peternakan broiler menunjukan bahwa ada peningkatan pengetahuan $26,6 \%$ dan sikap $35 \%$.

\section{DAFTAR PUSTAKA}

Akdon dan Riduwan. ( 2008 ). Rumues dan Data dalam Analisis Statistika. Bandung: Administrasi dan Manajemen. Bandung: Dewa Ruchi.

Ali-Olubandwa, A.M., Kathuri, N.J., dan Wesonga, T.E.O. 2011. "Effective extension methods for increased food production in Kakamega District"., Kenya: Egerton University. Journal of Agricultural Extension and Rural Development, Vol. 3 (5) : pp. 95.

Andi Arham,2012. Persepsi Masyarakat Terhadap Keberadaan Peternakan Burung Puyuh Di Kecamatan Pallangga Kabupaten Gowa, ( skripsi ) Jurusan Sosial Ekonomi Peternakan Fakultas Peternakan Universitas Hasanuddin Makassar.

Arikunto, S. 2006. Prosedur penelitian: suatu pendekatan praktik. Jakarta:Rineka Cipta.

Aw, Suranto. 2010. Komunikasi Sosial Budaya. Yogyakarta: Graha Ilmu.

Bilson Simamora.2002.Panduan Riset Prilaku Konsumen,P.Gramedia Pustaka, Jakarta

BPS,2018 s.d 2020. Sumber: Direktorat Jenderal Peternakan dan Kesehatan Hewan, Kementan.populasi ternak aym pedaging di indonesia
Fauziah, 2009. Upaya Pengelolahan Lingkungan Usaha Peternakan Ayam.http://uwityang yoyo.wordpress.com//2009/04/13/upaya.p engelolaan lingkungan.

Ginting,E.1991.Metode Kuliah Kerja Lapangan Universitas Brawijaya,Malang

Hardjosworo, P. S dan Rukmiasih, M. S, 2000, Meningkatkan Produksi Daging, Yogyakarta, Penebar Swadaya, Hlm. 10.

Mardikanto, T, 1993. Penyuluhan Pembangunan Pertanian. Sebelas Maret University Press, Surakarta

Mardikanto, T., 2014.CSR (Corporate Sosial Responsibility) Tanggung Jawab Sosial.Cetakan-1, Bandung, Alfabeta.

Margono.2004.metodologi penelitian pendidikan , Jakarta : Rineka Cipta

NHT.Siahan, 2004.Hukum Lingkungan dan Etologi Pembangunan Jakarta : Erlangga.

Nurjasmira,Rini.2014.Komunikasi Penyuluhan Pertanian Dalam Pemberdayaan Masyarakat Petani Pada Badan Pelaksanaan Penyuluhan Dan Ketahanan Pangan (Studi Kasus Pada Petani Di Kecamatan Gunung Kijang Kabupatenbintang). Jurnal Ilmu Administrasi Negara.

Nuzulul Muflihah A,2019.Analisi Dampak Lingkungan Dan Sosial Usaha Peternakanyam Pedaging Didesa Situmulyo Kecamatan Piyungan Kabupaten Bantul.Fakultas Peternakan Universitas Brawijaya

Padmowihardjo, 2002. Metode Penyuluhan Pertanian. Universitas Terbuka, Jakarta.

Padmowihardjo.S, 2002. Evaluasi Penyuluhan Pusat. Universitas Terbuka, Jakarta.

Peraturan menteri pertanian nomor : 50/permentan/ot.140/10/2006 tentang pedoman pemeliharaan unggas di pemukiman dengan rahmat tuhan yang maha esa

Peraturan menteri pertanian republik indonesia nomor 31/permentan/ot.140/2/2014 tentang pedoman budi daya ayam pedaging dan ayam petelur yang baik dengan rahmat tuhan yang maha esa menteri pertanian republik indonesia

Diterbitkan Oleh, 
DOI: 10.52625/j-agr-sosekpenyuluhan.v17i2.200

Permentan no 40/permentan/ot.140/7/2011 tahun 2011 peraturan

Rachmawati,S.2000.Upaya Pengolahan Lingkungan Usaha Peternakan Ayam.Balai Penelitian Veteriner.Wartazoa.Vol.9no.2hal 73-80

Sarwanto. D.2004,Model Pencemaran Limbah Peternakan Sapi Perah Rakyat Pada Beberapa Kondisi Fisik Alami Dan Sosial Ekonomi ( studi kasus di provinsi jawatengah).(Disertai) pascasarjan Institut

Setyono Dwi Joko Dan Ulfah Maria.2011.7 jurus sukses menjadi peternak ayam ras pedaging jakarta : swadaya.

Soedijanto, 2004. Menata Kembali Penyuluhan Pertanian Di Era Pembangunan Agribisnis. Departemen Pertanian. Bogor.
Sugiyono. 2003. Statistik Utuk Penelitian. Cv. Alfabeta, Bandung.

Sunarto,2003.Perilaku Organisasi.Yogyakarta: Amus Yogyakarta

Umar,H.2003.Studi Kelayakan Bisnis.Edisi 3.Pt Gramedia Pustaka Utama,Jakarta

Undang - undang RI No 16 Tahun 2006. Tentang Sistem Penyuluhan Pertanian, Perikanan, dan Kelautan. Biro Hukum Departemen Pertanian. Jakarta.

Walgito,B.(2002).Pengantar Psikologi Umum.Ed.3.Yogyakarta

Zakaria, 2006. Modul Dasar-Dasar Penyuluhan Pertanian. Pusat Manajemen Pelatihan Sumberdaya Manusia Pertanan, Ciawi. Bogor. 